\title{
Analysis of User Experience (UX) on Health-Tracker Mobile Apps
}

\author{
Amalia Suzianti, Rizky Puti Minanga, and Felisa Fitriani
}

\begin{abstract}
The development of smartphone technology allows people to do their daily activities in more efficient and effective ways through mobile applications. Therefore, the mobile apps industry has grown significantly in the last decade. To make the mobile apps industry develop further, knowledge on the elements needed in maximizing the user experience (UX) is necessary. The $\mathrm{UX}$ analysis in developing mobile apps has to be conducted in order to create an app that matches with user's preferences. This research focuses on one of the categories related to health, which is health-tracker apps. Based on the preliminary survey conducted, it was found that two of the most popular apps are the Google fit and Myfitnesspal. Thus, this research takes both apps as the objects of the research. The usability of the apps are then assessed by using AMOS-SEM. The results of the research is that Google fit had only one variable which is affect that influenced user's UX assessment while Myfitnesspal had two variables which are usability and affect that influenced it.
\end{abstract}

Index Terms-Continuance intention, health tracker, mobile apps, structural equation modelling, user experience.

\section{INTRODUCTION}

The development of technology has been growing enormously especially in terms of doing activity and acquiring information. Because of this, people find the need to find tools that can help them do things easier and more practical. The technology available today is enough to help people in doing their activities like educational, entertainment, productivity, social media, including health activities. The most used personal devices are PCs, laptops, tablets and smartphones.

Based on human current needs, a technology application needed is in the form of handheld devices (in this case smartphones) [1]. As the mobile network is getting better and stabilized, smartphone's application become a promising industry [2]. Android users can choose among more than 1.5 million apps and iOS users can choose among 1.4 million applications [3]. Among those applications, there are 50.25\% social media apps, $21.45 \%$ games-related apps, $10.14 \%$ business-related apps, $9.95 \%$ educational apps and $4.83 \%$

Manuscript received September 1, 2016; revised January 24, 2017.

This work was supported in part by the Direktorat Riset \& Pengabdian Masyarakat (DRPM), Universitas Indonesia. Analysis of User Experience (UX) on Health-Tracker Mobile Apps

Amalia Suzianti is with Universitas Indonesia, Depok, West Java, Indonesia 1642, now a researcher in Product Development and Innovation Laboratory (e-mail: suzianti@eng.ui.ac.id).

Rizky Puti Minanga was with Universitas Indonesia, Depok, West Java, Indonesia 16424 (e-mail: risky.puti41@ui.ac.id).

Felisa Fitriani is with Universitas Indonesia, Depok, West Java, Indonesia 1642, now a laboratory asssitant in Product Development and Innovation Laboratory (e-mail: felisa.fitriani@ui.ac.id). health-related apps [3].

This study aims to examine the interactions between people and systems (human computer interaction) and its relationship with Quality of Experience. Effort in improving the product based on its User Experience (UX) is an important thing [4]. UX is divided into two aspects, the pragmatic quality (efficiency and effectiveness) and hedonic quality (aesthetics, feelings of pleasure or interest) [4]. User Experience (UX) is the impact from appearance, function, performance, interactive behavior, and the ability of a system to support products or services [5].

By looking at the currently exist UX concepts, this study wanted to combine couple of UX concepts along with their elements to be modeled based on the Park, Han, Kim, Oh, \& Moon (2013) UX framework. By looking at the factors and indicators affecting the overall UX assessment, this study is expected to be able to determine what indicators are the most important in creating a system that is in line with the health-tracker app end user's expectation.

\section{ReSEARCH MethodOLOGY}

The data used in this study are primary data that was obtained by questionnaires distribution. Respondents are smartphone users who use health-tracker mobile apps, especially Google fit and Myfitnesspal. Total Respondents that were required in this study is at least 190 (19 indicators multiplied by 10) respondents. Methods of distributing questionnaires was carried out by using the surveymonkey.com website as an online media and distributing directly (manually) to the health-tracker application users.

The process of filling out online and offline questionnaires began on the fourth week in March 2016 and ended on May 13, 2016. From 527 respondents who filled the questionnaires, there were 452 which could be used as data samples. The other 75 filled questionnaires were considered incomplete or irrelevant with the research terms. After data gathering, the results will be analyzed using Structural Equation Modeling (SEM) with AMOS software 22. Based on the theory, SEM is a combination of factor analysis and regression analysis. SEM is a statistic modelling technique to examine the relationship between complex variables that are both recursive and non-recursive in order to obtain the overall picture of the model [6]. Various theories can be tested via SEM by testing the hypotheses through a set of constructs that correlate with each other. SEM is a form of evolution in multiple equation models combined from econometrics principle, the setting of psychology and sociology [7]. 


\section{A. Structural Model Specification}

User Experience (UX) model used in this study is based on the reference model by Park, Han, Kim, Oh, \& Moon (2013). The model describes the three variables that can affect the overall user experience (UX) which are usability, affect and user value. In each of these variables there are indicators (sub-element) that may affect the variables. [8]. The relationship between the UX elements can be built based on the model proposed by Pucillo and Cascini (2013), which shows that the pragmatic features (functionality or usability) can bring satisfaction, which is a sub-element of the user value. Then, hedonic features (influence or affect) can fulfill the users' needs and cause pleasure. Fulfilling the users' needs and pleasures is a sub-element of the model user [8]. So, it can be stated that the usability and affect can affect the overall UX user while it can also affect the user value [9].

There are three important things that affect the continuance intention to an interactive product - in this case mobile apps which are satisfaction, habit and customer value perspective [1]. Satisfaction is an important factor in explaining the continuance intention on information systems [10]. Literature on consumer behavior indicates that users' behavioral intention on the product or service can resulted in different meaning, such as the effects of dimension value variation that supposedly should be a predictor of the behavior. While the truth is, these three things are include as indicators on user value [8]. From here, we can try to see how their relationship or correlation works. Figure 1 shows a model of UX research.

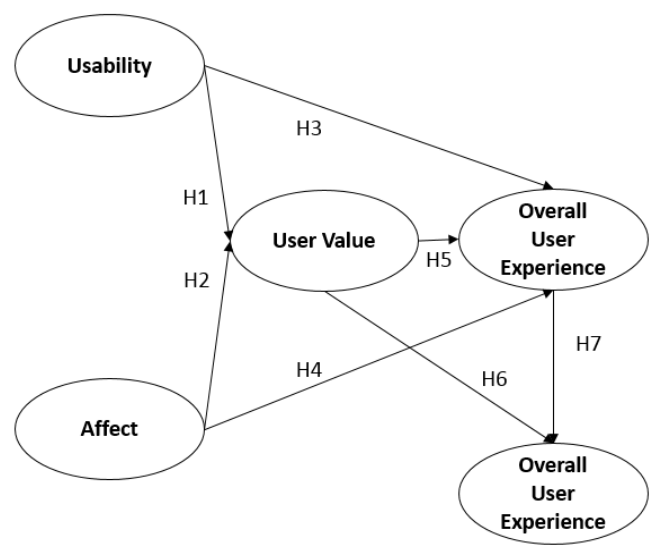

Fig. 1 Structural model.

\section{HYPOTHESES}

There are 7 hypotheses of this study, which are:

H1: Usability has a positive influence on user value

Usability is an objective assessment about ease of use degree in a system while user value is a subjective user assessment which tied with the system. This means that an ease of use degree has positive influence on subjective user assessment.

H2: Affect has a positive influence on user value

Affect is user's feeling regarding the system's appearance. This means that the effect of system's appearance towards user has positive influence on subjective user assessment.

H3: Usability has a positive influence on the Overall UX

Overall UX is the overall values of user's experience from the interaction with a service/product. This means that ease of use degree in a system has positive influence on overall UX.

H4: Affect has a positive influence on the Overall UX

This means that the effect of system's appearance towards user has positive influence on overall UX.

H5: User value has a positive influence on the Overall UX

This means that subjective user assessment has positive influence on the overall UX.

H6: User value has a positive influence on continuance intention

Continuance intention is the intention to continue using the system in the future. This means that subjective user assessment has positive influence on user's intention in continue using the system.

H7: Overall UX has a positive influence on continuance intention

This means that overall UX has positive influence on user's intention in continue using the system.

\section{REsults}

\section{A. Validity and Reliability Questionnaire}

Before the questionnaire was fully distributed, a pretesting was needed. Pretesting is a way to test the questionnaire by distributing it to a small number of respondents. These respondents fixed the questionnaire, identified and eliminated possible problems that could occur [11]. This was done by using the initial 30 samples to test the reliability and validity of each variable.

The indicator items were deemed reliable, consistent and relevant to the variables, with a minimum limit of 0.6 Cronbach alpha [11]. KMO value and the factor loading value with 0.5 as the minimum value became the ascertainment of data validity. (Malhotra, 2010) (Table I). Based on the table, it showed that the UX data assessment for Myfitnesspal is above the minimum value for the reliability test and validity test that used Cronbach alpha and KMO \& Barrets test.

\begin{tabular}{|c|c|c|}
\hline \multicolumn{2}{|c|}{ TABLE I: REALIBILITY AND VALIDITY OF DATA } \\
\hline Variable & $\begin{array}{c}\text { Cronbach Alpha } \\
\text { Myfitnesspal }\end{array}$ & $\begin{array}{c}\text { KMO Barrets } \\
\text { Test }\end{array}$ \\
\hline Affect & 0.793 & 0.784 \\
\hline Usability & 0.879 & 0.877 \\
\hline User Value & 0.801 & 0.808 \\
\hline $\begin{array}{c}\text { Continuance } \\
\text { Intention }\end{array}$ & 0.616 & 0.500 \\
\hline Overall & 0.950 & 0.951 \\
\hline
\end{tabular}

\section{B. Model Estimation}

After running the UX data model using SEM with the flow diagram shown in Fig. 2 - which consisted of latent constructs with their empirical constructs - we estimate the early stage model in the Google fit data before respesification. This also showed the estimated value for each arrow from variables to the indicators and the estimated value between variables.

Figure in estimation column (Table II) shows the factor 
loading of each indicator to related construct. A good factor loading should be greater than 0.5 and ideally above 0.7 [7]. In this study, the limit used was 0.5 . Factor loading above 0.5 showed that an indicator was a part of the construct or variable. Based on Table II, it showed the value of each construct and the decision whether to maintain or remove the indicator.

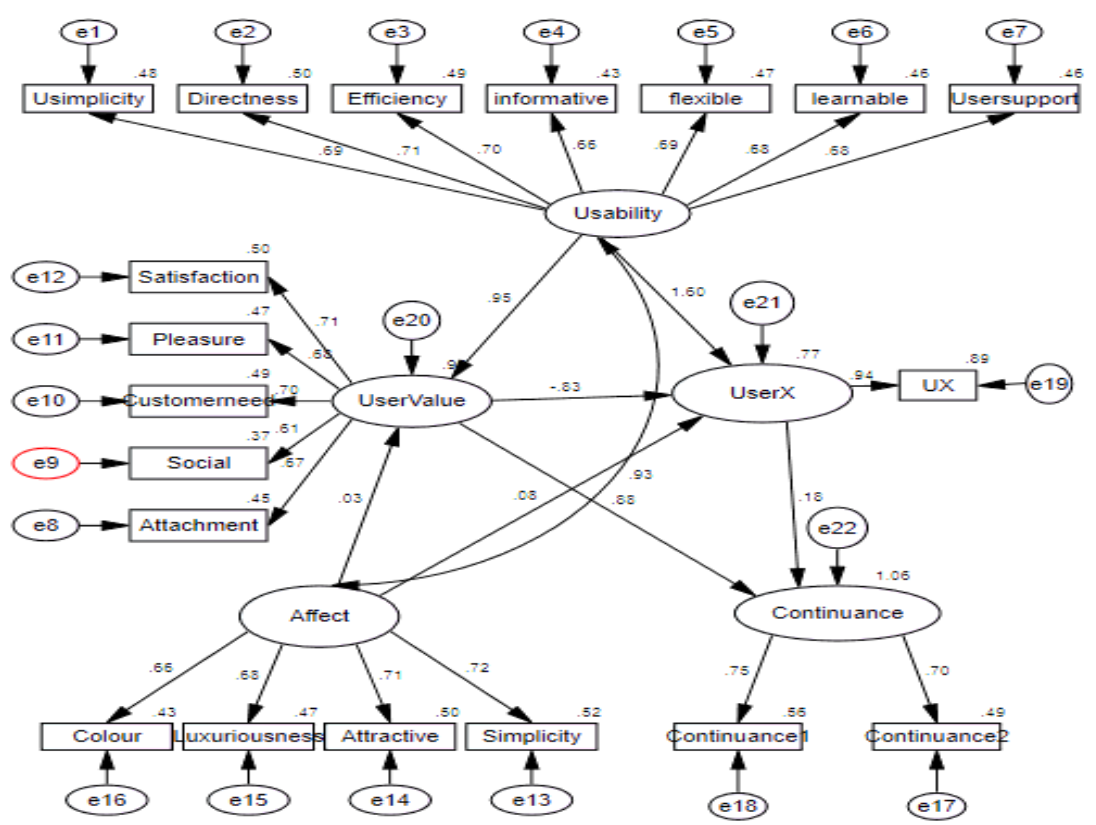

Fig. 2 UX model estimation results on SEM.

TABLE II: MODEL PARAMETER ESTIMATION

\begin{tabular}{|c|c|c|c|c|}
\hline & & & Myfitnesspal Estimation & Googlefit Estimation \\
\hline USimplicity & $\begin{array}{l}<-- \\
--\end{array}$ & Usability & 0.696 & 0.713 \\
\hline Directness & $<--$ & Usability & 0.758 & 0.739 \\
\hline Efficiency & $<--$ & Usability & 0.684 & 0.706 \\
\hline Informative & $<--$ & Usability & 0.74 & 0.679 \\
\hline Flexible & $<--$ & Usability & 0.674 & 0.684 \\
\hline Learnable & $<--$ & Usability & 0.717 & 0.703 \\
\hline Usersupport & $<--$ & Usability & 0.696 & 0.7 \\
\hline Attachment & $<--$ & UserValue & 0.7 & 0.72 \\
\hline Sociable & $<--$ & UserValue & 0.547 & 0.624 \\
\hline Customerneed & $<--$ & UserValue & 0.717 & 0.743 \\
\hline Pleasure & $<--$ & UserValue & 0.664 & 0.695 \\
\hline Satisfaction & $<--$ & UserValue & 0.714 & 0.763 \\
\hline Simplicity & $<--$ & Affect & 0.69 & 0.736 \\
\hline Attractiveness & $<--$ & Affect & 0.752 & 0.755 \\
\hline Luxurious & $<--$ & Affect & 0.649 & 0.709 \\
\hline Colour & $\begin{array}{ll}<-- \\
\end{array}$ & Affect & 0.699 & 0.704 \\
\hline Cont 2 & $<--$ & Continuance & 0.712 & 0.806 \\
\hline Cont1 & $\overline{<---}$ & Continuance & 0.649 & 0.812 \\
\hline UX & $<---$ & UserX & 0.865 & 0.986 \\
\hline
\end{tabular}

\section{Goodness of Fit and Repesifications}

In addition to see whether the model was fit with the existed data, the goodness of fit test was conducted. The model respesification was done by modifying the model based on the reference given from GOF. After respesification, there's a significant improvement on GOF statistic. With the respesification, the goal can be obtained using more specific value so the standard can be fulfilled. On Google fit, after respesification the Chi-square value was decreased to 358.804, GFI, NFI, CFI value became good fit value, RMSE value was closer to the limit although it still exceeded the limit, the ECVI value was closer to saturated model, and the value of AGFI and PGFI were also higher than before.

For Myfitnesspal, the Chi-square value was decreased to 574.278, the GFI was higher with 0.865 and became marginal fit, RMSE value was closer to the limit although it still exceeded the limit, the ECVI value was closer to 
still exceeded the limit, the ECVI value was closer to saturated model, and the value of AGFI, NFI and PGFI had become marginal fit while CFI had become a good fit.

\section{DISCUSSION}

\section{A. Assessment Model Analysis}

In the assessment model, the indicator was considered to be accepted or met the standard value if the value was above 0.05 . The following explanation will explain the assessment from each variables and also sort the indicators' prioritization in aiming to develop application further and its prioritization in creating UX model.

\section{B. Usability}

From Table III it can be seen that in the development of an application what should be prioritized is the ease of controlling an application (directness). Based on the existing data, both Google fit and Myfitnespal apps had different order of priorities, but both were prioritizing directness. Differences in priorities occured might due to differences in each of their features, thus making the user ratings to the usability variables different in terms of the priority. However, based on the score obtained, directness, informativeness, learnability, efficiency and simplicity had a high priority as well.

\section{Affect}

Based on Table 3 it can be seen that in the development of mobile apps, the priority was users' attractiveness toward the mobile apps interface design. Based on the data, both Google fit and Myfitnespal had different order of priorities, but both had attractiveness as their number one priority. It can also be seen that the color aspect is in higher order on Google fit.

\section{User Value}

Based on Table III it can be seen that in the development of an application end user's satisfaction toward all mobile apps' features should be prioritized. Based on existing data both Google fit and Myfitnespal have the same priorities scale. This information can be a reference in developing new mobile apps.

TABLE III: PRIORITY INDICATORS

\begin{tabular}{|c|c|c|c|c|c|c|c|}
\hline Variable & Indicator & $\begin{array}{l}\text { Loading } \\
\text { factor }\end{array}$ & Priority & Variable & Indicator & $\begin{array}{l}\text { Loading } \\
\text { factor }\end{array}$ & Priority \\
\hline \multirow{7}{*}{$\begin{array}{l}\text { Usability } \\
\text { (Google } \\
\text { fit) }\end{array}$} & Directness & 0.739 & 1 & \multirow{7}{*}{$\begin{array}{l}\text { Usability } \\
\text { (Myfitnesspal) }\end{array}$} & Directness & 0.769 & 1 \\
\hline & Efficiency & 0.719 & 2 & & $\begin{array}{l}\text { Informativenes } \\
\mathrm{s}\end{array}$ & 0.737 & 2 \\
\hline & Simplicity & 0.701 & 3 & & Learnability & 0.732 & 3 \\
\hline & User Support & 0.688 & 4 & & Efficiency & 0.695 & 4 \\
\hline & Learnability & 0.686 & 5 & & Simplicity & 0.692 & 5 \\
\hline & Flexibility & 0.670 & 6 & & User Support & 0.692 & 6 \\
\hline & $\begin{array}{l}\text { Informativenes } \\
\mathrm{s}\end{array}$ & 0.658 & 7 & & Flexibility & 0.689 & 7 \\
\hline \multirow{4}{*}{$\begin{array}{c}\text { Affect } \\
\text { (Google } \\
\text { Fit) }\end{array}$} & Attractiveness & 0.755 & 1 & \multirow{4}{*}{$\begin{array}{l}\text { Affect } \\
\text { (Google Fit) }\end{array}$} & Attractiveness & 0.755 & 1 \\
\hline & Simplicity & 0.736 & 2 & & Simplicity & 0.736 & 2 \\
\hline & Luxurious & 0.709 & 3 & & Luxurious & 0.709 & 3 \\
\hline & Colour & 0.704 & 4 & & Colour & 0.704 & 4 \\
\hline \multirow{5}{*}{$\begin{array}{c}\text { User } \\
\text { Value } \\
\text { (Google } \\
\text { fit) }\end{array}$} & Satisfaction & 0.763 & 1 & \multirow{5}{*}{$\begin{array}{c}\text { User Value } \\
\text { (Myfitnesspal) }\end{array}$} & Satisfaction & 0.736 & 1 \\
\hline & Customer need & 0.743 & 2 & & Customer need & 0.732 & 2 \\
\hline & Attachment & 0.720 & 3 & & Attachment & 0.686 & 3 \\
\hline & Pleasure & 0.695 & 4 & & Pleasure & 0.686 & 4 \\
\hline & Sociable & 0.624 & 5 & & Sociable & 0.546 & 5 \\
\hline
\end{tabular}

\section{E. Structural Model Analysis}

Based from the table 4, it was found that in both Google fit and Myfitnesspal the user value was positively affected by usability and affect variables, which means that the user's satisfaction was affected by application's functional side and its appearance. The user's rating on Google fit's overall UX was affected significantly by its appearance (affect) and wasn't affected by user value and usability. On Myfitnesspal, the overall UX's rating was affected by both affect and usability. This means that both apps had significantly affected because of their appearances. Overall UX and user value gave positive effect on continuance intention, meaning that it affected user's intention whether or not to keep using the apps. 
TABLE IV: RESULTS OF THE ASSESSMENT PARAMETERS

\begin{tabular}{|c|c|c|c|c|c|c|}
\hline Hypothesis & Correlation & S.E. & C.R. & $\mathrm{P}$ & accepted? & Apps \\
\hline H1 & User value <--- Usability & 0.151 & 3.839 & $* * *$ & Yes & \multirow[t]{6}{*}{ Myfitnesspal } \\
\hline $\mathrm{H} 2$ & User value <--- Affect & 0.142 & 2.5 & 0.012 & Yes & \\
\hline H3 & User Experience <--- Usability & 0.248 & -0.443 & 0.658 & No & \\
\hline $\mathrm{H} 4$ & User Experience <--- Affect & 0.376 & 3.834 & $* * *$ & Yes & \\
\hline H5 & User Experience <--- User Value & 0.313 & -0.695 & 0.487 & No & \\
\hline H6 & Continuance <--- User Value & 0.113 & 4.934 & $* * *$ & Yes & \\
\hline $\mathrm{H} 1$ & User value <--- Usability & 0.151 & 3.839 & $* * *$ & Yes & \multirow[t]{7}{*}{ Google Fit } \\
\hline $\mathrm{H} 2$ & User value <--- Affect & 0.142 & 2.5 & 0.012 & Yes & \\
\hline H3 & User Experience <--- Usability & 0.248 & -0.443 & 0.658 & No & \\
\hline $\mathrm{H} 4$ & User Experience <--- Affect & 0.376 & 3.834 & $* * *$ & Yes & \\
\hline H5 & User Experience <--- User Value & 0.313 & -0.695 & 0.487 & No & \\
\hline H6 & Continuance <--- User Value & 0.113 & 4.934 & $* * *$ & Yes & \\
\hline $\mathrm{H} 7$ & Continuance <--- User Experience & 0.127 & 3.534 & $* * *$ & Yes & \\
\hline
\end{tabular}

\section{CONCLUSION}

There are differences found in Myfitnesspal and Google fit research results. User value was found to have no significant effect in user's rating on overall UX. In Google fit, there were two variables which had no effect on user's rating. Those two variables were user value and usability. This can happen because of the difference in expectation of the users toward both applications. From both user preferences data, the variables that give significant effect was affect or apps' appearance.

In creating the health-tracker apps that fulfill the users' need, this can be done by looking at the strongest variables that give positive effect and the indicator prioritization. With affect, the priorities were attractiveness, color, simplicity, luxuriousness. In usability, the priorities were directness, informativeness, learnability, efficiency and simplicity. On user value, the priorities were satisfaction, customer need, attachment, pleasure and sociable. Other than user experience, the other important aspect was continuance intention. Based on the research, it's found that there was a significant effect from user experience to its continuance intention.

For the future research, what can be done is to conduct user experience assessment with experimental method and to select more specific subject so that the more precision result can be obtained. Using additional tools like QFD questionnaires for the new product development and also adding FcQCA analysis can complete the SEM analysis.

\section{ACKNOWLEDGMENT}

We would like to give our sincerest gratitude to direktorat riset \& pengabdian masyarakat (drpm), universitas indonesia, for funding this study. Thus, this study can be properly carried out and produce such results. This research was also made possible by the support and assistance of a number of people. We would like to thank for their valuable and constructive opinions.

\section{REFERENCES}

[1] H. Chun-Hua and J.-j. C, "Exlporing the influential factors in continuance usage of mobile social Apps: Satisfaction, habit and customer perspectives," Telematic and Informatic, pp. 342 -355, 2016.

[2] H. Hartmut and V. Viswanath, "Mobile application usability: Conceptualization and instrument development," MIS Quarterly, vol. 39, no. 2, pp.435-472, 2015.

[3] The statistics portal. (2015). Most popular Apple App Store categories in March 2015, by share of available apps. Retrieved from http://www.statista.com/statistics/270291/popular-categories-in-the-ap p-store/2015.

[4] M. Rauschenberger, M. Schrepp, S. Olschner, J. Thomaschewski, and M. P. Cota, "Efficient measurement of the user experience of interactive product," International Journal of Artificial Intelligence and Interactive Multimedia, vol. 2, no. 1, 2013.

[5] F. Pucillo and G.Cascini, "Framework for user experience, needs, and affordance," Design Studies, pp. 160-17, 2013.

[6] Zuhri and Sarika. Analisis Hubungan Antar Variabel Dalam Kegiatan wisata Medis ke Malaysia Menggunakan Structural Equation Modellin, Depok: Universitas Indoensia, 2014.

[7] J. Hair, et al, Multivariate Data Analysis, Prentice -Hall, Inc., New Jersey, 1984.

[8] J. Park, S. H. Han, H. K. Kim, S. Oh, and H. Moon, "Modeling user experience: A case study on a mobile device," International Journal of Industrial Ergonomics, pp. 187-196, 2013.

[9] T. A. Nanda, Permodelan User Experience Sistem Operasi Komputer Personal Pada Masa Orientasi, Depok: Universitas Indonesia, 2015.

[10] A. Bhattacherjee, "Understanding information system continuance an expectation confirmation model," $M I S Q$, vol. 25, no.3, pp. 351 - 370, 2001.

[11] Malhotra and K. Naresh, Marketing Research an Applied Orientation. New Jersey: Pearson, 2010.

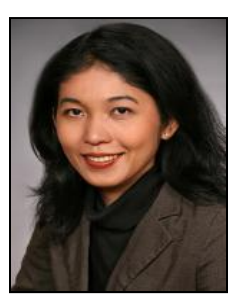

Amalia Suzianti was born in Ujung Pandang, December 25, 1978 and holds a Ph.D in innovation system design from Technische Universitaet Berlin, Germany and University of Luxembourg (2010), master of science in technology and innovation management from Brandenburgische Technische Universitaet Cottbus, Germany (2004), and a bachelor of engineering in industrial engineering from Universitas Indonesia (2000).

Currently, she is a lecturer and senior researcher in the Department of Industrial Engineering, Faculty of Engineering, Universitas Indonesia. Prior joining Universitas Indonesia in late 2010, she has acquired international 
academic and professional work experiences, mainly in Europe, Asia and Latin America. She has involved in various multinational projects in different industries such as automotive (Daimler Benz, Germany), consumer goods (Givaudan SA Europe, Unilever Europe), IT (Siemens Europe and Singapore) and energy (Total Germany). She had also been actively publishing researches and journals in various publishers.

Dr. Suzianti' research interests lie in the fields of New Product and Service Development, Technology and Innovation Management, Technology Policy and Sustainable Innovation. She is also a member of Product Development and Management Association (PDMA) and Design Society (DS). She is currently active as the Head of Product Development and Innovation Laboratory and Vice Head of Industrial Engineering Department, Universitas Indonesia.

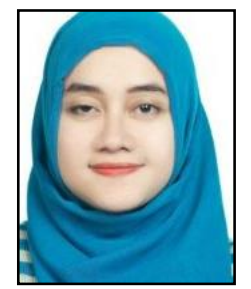

Rizky Puti Minanga was born in Depok, October 27, 1990 is a graduate student from Universitas Indonesia. Currently, she holds a master of engineering from Industrial Engineering, Universitas Indonesia (2016) and bachelor degree in chemistry from Universitas Indonesia (2013).

She has involved herself in several working industries including Commonwealth Bank (2015), PT Pertamina EP (2014) and PT Dynaplast (2013). Her interest lies among strategic planning, continuous improvement, quality sistem and biochemistry.

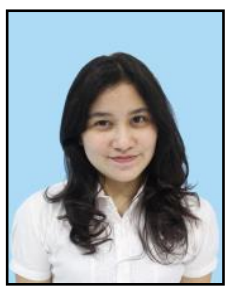

Felisa Fitriani was born in Jakarta, December 9, 1995 is currently studying for her bachelor degree in Industrial Engineering, Universitas Indonesia. She is expected to graduate with a bachelor of engineering title on 2017.

As she is still a student, she has been developed herself in internship experiences. She was previously an intern for PT Telekomunikasi Selular (2016) and Lazada Indonesia (2016). Her research interest lies in product development, industrial design, quality system and business development.

Ms. Fitriani is currently a laboratory assistant in product development and innovation, one of the laboratory in Industrial Engineering, Universitas Indonesia. As the laboratory assistant, she helps doing researches along with other researchers and lab assistants and has joined several researches held by the lab. 